\title{
El conflicto social y político colombiano en los libros de texto escolar de ciencias sociales: representación, diversidad y narrativa
}

\section{The Colombian Social and Political Conflict in Social Sciences Secondary School Textbooks: Representation, Diversity and Historical Narrative}

\author{
Miguel Ángel Gómez Mendoza \\ mgomez@utp.edu.co \\ María Victoria Alzate Piedrahita \\ mvictoria@utp.edu.co \\ * Universidad Tecnológica de Pereira, Colombia
}

\section{Resumen:}

Se analiza el contenido y la representación del conflicto "social" y "político" que caracteriza a la sociedad colombiana, sobre cuya definición y carácter no existe consenso, en un "corpus" de libros de texto escolar de ciencias sociales de grados $9^{\circ}, 10^{\circ}$ y $11^{\circ}$ de la escuela secundaria publicados en Colombia durante el periodo comprendido entre 1999 - 2011. Este análisis de contenido se realiza desde dos perspectivas: de una parte, especializada y académica, la segunda, sobre la definición y las diversas concepciones que sobre el "conflicto" colombiano en literatura académica y científica especializada, y de otra, desde el contenido de los libros de texto escolar colombianos de ciencias sociales. Se empleó una metodología de análisis de contenido para contrastar la literatura especializada sobre el "conflic-

\begin{abstract}
:
This study analyzes the content and the representation of the "social" and "political" conflict that characterizes Colombian society, upon whose definition and nature there is no consensus, in a "corpus" of Social Sciences Secondary School textbooks (grade 9, 10 and 11) published in Colombia for the period between 19992011. This content analysis is done from a double perspective. On the one hand, it reviews the diverse conceptions about the Colombian "conflict" in specialized academic and scientific literature. On the other hand, Colombian High School Social Sciences textbooks are analyzed. A content analysis methodology was used to contrast the literature about the "conflict" and how textbooks describe and represent it.
\end{abstract}

1 Dirección para correspondencia (correspondence address):

María Victoria Alzate Piedrahita. Facultad de Ciencias de la Educación. Universidad Tecnológica de Pereira. La Julita. Pereira-Risaralda (Colombia). 
El conflicto social y político colombiano en los libros de texto escolar de ciencias sociales: representación, diversidad y narrativa

Miguel Ángel Gómez Mendoza y María Victoria Alzate Piedrahita

to" y la manera como los libros de texto narran y representan de manera diversa el conflicto.

\section{Palabras clave:}

Representación; Conflicto Social y Político; Libros de textos escolares en Ciencias Sociales.

\section{Key words:}

Representation; Social and Political Conflict; School textbook in Social Sciences.

\section{Résumé :}

Nous analyserons le contenu et la représentation du conflit « social» et «politique»qui caractérise la société colombienne. Il n'existe pas de consensus quant à sa définition et son caractère, dans un " corpus » de manuels scolaires de sciences sociales pour les classes 9, 10 et 11 de l'école publique colombienne pour la période allant de 1999-2011. Cette analyse de contenu a été faite selon deux perspectives ; d'une part, spécialisée et universitaire, d'autre part, suivant les diverses conceptions de " conflit » dans la littérature scientifique spécialisée. Puis, le contenu des manuels scolaires de sciences sociales en Colombie, leurs aspects et leurs définitions. Une méthodologie d'analyse du contenu a été utilisée pour comparer la littérature sur le « conflit » et la manière dont les manuels scolaires le décrivaient et le représentaient.

\section{Mots clés:}

Représentation; Conflit social et politique; Manuel scolaire en sciences sociales.

Fecha de recepción: 24-5-2017

Fecha de aceptación: 20-9-2017

\section{Introducción}

Gustavo Duncan (2017), Ilama la atención sobre las interpretaciones y el juego de intereses que circulan en los medios de comunicación y el mundo universitario sobre el denominado "conflicto" colombiano. Dos caras de la moneda se pueden plantear para hacer un balance contemporáneo de este complejo fenómeno.

Una cara: el "conflicto" fue entre iguales. En primer lugar, considera que la construcción de la memoria histórica, como un ejercicio que asigna las responsabilidades en el conflicto y define la naturaleza de las víctimas y de los victimarios, dista de ser un ejercicio pasivo en términos políticos. La construcción de memoria es, para él, en esencia un ejercicio político. En segundo lugar, implica un sentido de justicia, la asignación de responsabilidades implica que unos sectores de la sociedad, por los daños causados, deberán comprometerse con concesiones que incluyen cambios en la distribución de obligaciones y recursos en el orden social.

Pero, además, necesariamente conduce a procesos de legitimación y 
reivindicación de unos actores, al tiempo que deslegitima y cuestiona a otros. En efecto, los actores que en la elaboración de la memoria queden retratados como responsables, en mayor o menor grado, estarán obligados a ceder influencia política. Mientras que quienes tengan habilidades para ser retratados como víctimas y, sobre todo, quienes sepan asumir el papel de jueces morales y públicos de las actuaciones de terceros durante el conflicto, tendrán una oportunidad de oro para reclamar posiciones de poder en el Estado y en los partidos políticos. En tercer lugar, Duncan (2017), aprecia que como consecuencia, de la asignación de oportunidades respecto al Estado y los partidos políticos colombianos, para las Farc es tan importante situar la discusión de las responsabilidades en el conflicto en la definición de los perpetradores más allá de los combatientes y de los ejecutores directos. Es una victoria política porque borra la distinción entre las élites políticas y económicas y quienes ejecutaron la violencia contrainsurgente, bien fueran militares o paramilitares, y de paso equipara su situación a la de la jefatura de las Farc que, como se sabe, tuvo una responsabilidad directa por haber dirigido el ejército insurgente sobre el terreno.

Otra cara: la guerrilla un actor descompuesto. La otra cara de la moneda son los ejercicios de memoria histórica que retratan a la insurgencia como un actor descompuesto por la codicia. La ideología insurgente es una mera fachada de organizaciones terroristas para legitimar la acumulación de riqueza privada desde el narcotráfico y demás economías criminales. Por supuesto, bajo esta versión la legitimidad de las Farc es mínima, así como su viabilidad como un actor que reclama espacios políticos dentro de las instituciones de la democracia. El objetivo es neutralizar cualquier aspiración política de los jefes de las Farc y de los sectores ideológicos afines.

Se concluye, así que entre estos dos extremos, más allá de que los autores sean conscientes o no de sus sesgos ideológicos, se mueve la producción científica sobre el tema. Y es inevitable que cualquier producto de la investigación tenga efectos políticos en la forma cómo la sociedad interpreta el conflicto y, por consiguiente, en la forma cómo se elabora la memoria histórica. Pero una cosa son los académicos con sesgos ideológicos y otra los académicos con una agenda política, en que el propósito es acomodar la interpretación de lo sucedido para que un grupo político en particular salga favorecido en la redistribución del poder. De este detalle dependerá el papel de la academia colombiana en los ejercicios de 
memoria durante el postconflicto, afirma Gustavo Duncan.

¿Por qué estudiar el conflicto desde las representaciones y las narrativas históricas? El presente no es nunca idéntico con el pasado, parece obvia esta afirmación, pero no lo es. En el presente coexisten representaciones y narrativas sobre el pasado que se configuran en tejidos a menudo muy diferentes. La historia imagina respuestas (representaciones y narraciones) diferentes, en este caso, sobre el Ilamado "conflicto" colombiano. ¿Qué nos puede enseñar la historia del "conflicto"? Fuera de unas ideas y valores muy generales, que el pasado no puede ser pensado, de modo razonable, sino en términos del presente. Como sujetos sociales nos encontramos con nuestros propios discursos, narraciones y representaciones sobre la historia porque esta no es más que un argumento adicional de validación de nuestras propias opciones. No es el caso ignorar el potencial educativo de la historia. Pero, una vez más, la decisión, buena o mala, de asumir unas "enseñanzas" cae en su totalidad en nuestra responsabilidad.

En este contexto, las preguntas básicas de investigación que orientaron el trabajo realizado fueron: (1) ¿Cuál es la narrativa, la "tipología" y la caracterización de los elementos históricos, políticos, económicos y culturales del denominado "conflicto" colombiano que se expone en el "corpus" documental especializado base del estudio, a saber: informe: "Contribución al entendimiento del conflicto armado en Colombia. Comisión Histórica del Conflicto y sus Víctimas" (CHCV). Febrero de 2015"? (2) ¿Cuál es el papel que juegan los contenidos de los libros de texto escolar de ciencias sociales en la construcción de identidades y en la transmisión de concepciones históricas y configuración de ámbitos de significado y valores sobre la representación del conflicto social colombiano?

\section{Marco teórico}

\section{El conflicto social y político en las ciencias sociales: representación}

En la literatura especializada el sentido de la noción de conflicto político destaca tres características: (1) los conflictos políticos oponen grupos en el sentido más general de la expresión: clases o capas sociales, comunidades étnicas o confesionales; naciones, nacionalidades, organizacio- 
nes sociales (partidos, Estados, asociaciones de estado, grupos armados con fines políticos, etc.); (2) en todo conflicto político, las instituciones estatales están, de una u otra manera, implicadas. El Estado es parte del conflicto, juega un papel, árbitro o mediador del conflicto; (3) un conflicto requiere una solución política. Por esta se entiende comúnmente una resolución obtenida por la discusión y oposición al uso de la violencia. Esta solución puede ser o no hallada. Luego la alternativa entre violencia y discusión está en el corazón de los conflictos políticos y sociales contemporáneos en Colombia.

En este contexto, Otto \& Stöber (2011), Entelman (2002) y Korinman (2005), consideran que en los conflictos, a menudo se distinguen diferentes aspectos: "conflicto latente", "la comunicación y la definición del conflicto", "generación de conflictos"; "Manifiesto de los conflictos", "gestión de conflictos" y "resolución de conflictos" o "la escalada del conflicto". Desde la perspectiva de la "Educación y el conflicto", Tawil \& Harley (2004:), plantea sus etapas así: "sin conflictos", "la paz relativa", "problemas internos", "disturbios sociales", "conflicto y conflicto armado", "la transición de la violencia", "proceso de paz", "post-conflicto", para referirse implícitamente al apoyo que deben recibir las sociedades inmersas en este tipo de etapas de los conflictos armados o guerras.

Hay variadas distinciones entre tipos de conflictos, se puede plantear, además de las ya comentadas, una tipologías de conflictos y los criterios utilizados para su establecimiento, resolución o solución, a saber: (1) según las posiciones de las partes en el conflicto: antagónicas - no antagónicas para poner en peligro las relaciones de poder; (2) conflicto según las partes en conflicto: balanceado - desequilibrado; (3) forma de resolución de conflictos: informal - regulada / institucional; (4) según las posibilidades de resolución de los conflictos: consensuales - disenso; constructivas - destructivas; (5) con frecuencia se diferencian los conflictos por sus causas, por ejemplo, "religioso" o se habla de conflictos "étnicos". La tradición teórica y empírica de ciencias sociales, como la sociología y la ciencia política, entre otras, ofrecen modelos y tipologías del "conflicto" cuya actualización y uso contemporáneo es muy útil heurísticamente hablando, para su comprensión en los ámbitos institucionales y en las herramientas o medios (libro de texto escolar) propios de la escolaridad. 


\section{¿Por qué estudiar el conflicto en los libros de texto escolar?}

Como lo exponen Guerra \& Plata (2005), en Colombia se han realizado más de un centenear de proyectos de investigación académica o universitaria relacionados con el conflicto colombiano. Lo anterior ha servido para conformar una capacidad de investigación en los temas del conflicto, la convivencia y la democracia. Buena parte de los resultados de estos proyectos "hacen parte hoy del mundo académico, a través de publicaciones, también se han incorporado a la reflexión y el diseño de políticas públicas. No obstante hace falta conocimiento." (p. 90). En este contexto, cierta "falta" o "ausencia" de conocimiento sobre el "conflicto" colombiano en los libros de texto escolar, es uno de los argumentos a desarrollar para justificar una indagación coomo la realizada. Igualmente, los libros de texto escolar de ciencias sociales y de historia son una especie de "autobiografías" de los Estados y las naciones, dan cuenta de la interpretación del pasado que una sociedad quiere transmitir a sus futuras generaciones.

A diferencia de otros productos historiográficos, los libros de texto escolar tienen el respaldo de un amplio consenso social. Ello los convierte en una especie de sismógrafo del estado de ánimo -o al menos de amplios sectores de ella- y de los conflictos que vive y de la manera como los asume y pretende resolverlos. Este tipo de textos son entonces fascinantes fuentes primarias para el estudio científico e instrumentos políticos contemporáneos. El trabajo con libros de texto escolar de ciencias sociales adquiere especial delicadeza por su manejo de los conflictos que exponen y tratan y las imágenes propias y ajenas que vehiculan: cuando se trata de la imagen del otro en contextos conflictivos, se tiene que ver al mismo tiempo con la imagen propia. Es importante entonces realizar estudios que cuestionen y pongan en entredicho hábitos, representaciones, ideologías, juicios y acciones que contienen los libros de texto escolar, en nuestro caso específico, la representación y comunicación del conflicto social y político en la sociedad colombiana a través de los libros de texto escolar de ciencias sociales contemporáneos.

\section{La naturaleza del conflicto político y social colombiano: narrativas históricas}

"¿Por qué no somos capaces de ver la guerra civil que el mundo entero sí ve en Colombia?" este era el interrogante que planteaba en el año 
2000 el diario nacional colombiano El Espectador, y que estaba particularmente motivado por las reflexiones de un ensayo de William Ramírez (2000), donde se sugiere que en el país se "está configurando una nueva forma de guerra civil de cuyo diagnóstico oportuno y preciso depende, en gran medida, su solución" (p.25).

Ramírez y el diario colombiano El Espectador, no han sido los únicos en sugerir que el conflicto colombiano debe definirse como una "guerra civil". Así, la tendencia a definir el conflicto colombiano como una "guerra civil" ha recibido serios cuestionamientos. Según Uricoechea, "calificar el conflicto armado en Colombia como una guerra civil no es sólo objetivamente incorrecto, sino, lo que es aún peor, políticamente perverso". Pizarro (2000), a su turno, señala que "en Colombia constituye una grave torpeza intelectual hablar de guerra civil". Fernando Cepeda (2001) también ha advertido sobre el "manejo ligero" de muchos conceptos alrededor de los problemas nacionales -entre ellos, el de "guerra civil"-. Daniel Pécaut (2001), formula reparos al uso de dicha expresión para explicar la naturaleza del conflicto colombiano. Así, unos aprecian que en Colombia no existió una guerra civil sino "una guerra contra la sociedad civil", mientras que otros adoptan una perspectiva opuesta: existe un "legitimo conflicto social" en Colombia que justifica el uso de la violencia mientras no se resuelvan las evidentes y profundas diferencias sociales existentes y se abran nuevas posibilidades de participación política, como sostiene el historiador Medofilo Medina (2003).

En reiteradas ocasiones ha planteado el historiador Eduardo Posada Carbó (2003, 2003a), que el ejercicio de discutir la validez de estos conceptos no significa, de manera alguna, restarle gravedad al conflicto o minimizar sus dimensiones. No se trata tampoco de una discusión meramente semántica. Ni de un debate teórico y abstracto. Las visiones de los intelectuales sobre una sociedad particular no pueden disociarse del lenguaje que les sirve para analizarla. Pero la claridad de conceptos en el caso que nos ocupa es de interés más que todo por profundas razones prácticas. Interesa, en primer lugar, al propio camino escogido domésticamente para lograr la paz en Colombia. Cualquier concepto que se seleccione estaría definiendo la naturaleza del conflicto y condicionando así la gama de posibilidades para enfrentar su solución. Interesa, en segundo lugar, a las relaciones formales entre el país y el mundo externo.

La aplicación del derecho internacional ha estado tradicionalmente determinada por la forma como se clasifiquen los conflictos, e intere- 
sa, finalmente, a las relaciones informales con la llamada comunidad internacional. El historiador Marco Palacios (2001), cuando se refiere al carácter de legitimidad que tiene el Estado colombiano, decía que "... Para legitimar el futuro no es necesario deslegitimar el pasado" (p. 12) Durante las últimas décadas, logró arraigarse entre amplios sectores de Colombia un discurso deslegitimador, del pasado y del presente, cuyas dimensiones y efectos deberían ser motivo de serias preocupaciones.

El discurso deslegitimado se podría resumir así: existe un serio "conflicto social" en Colombia porque no existe un Estado legítimo. Para Posada Carbó (2003a), la noción según la cual el Estado colombiano sería "ilegítimo" ha calado de manera significativa entre destacados formadores de opinión, académicos, intelectuales y columnistas de prensa. Quienes le niegan al Estado su condición legítima aducen, por lo general, a su falta de representatividad, sus fracasos en la provisión del bien común, y la escasa confianza ciudadana en sus instituciones.

Si bien urge rectificar la falsa y errada noción de la "ilegitimidad" del Estado colombiano. Ello no quiere decir que no existan aquí problemas de legitimidad. Pero el abuso del término para referirse a la totalidad del Estado colombiano no le hace justicia a su estructura compleja, ni a las conquistas democráticas de la sociedad colombiana. Dos áreas asociadas al conflicto, son especialmente relevantes cuando se considera ilegítimo el Estado colombiano: "la reforma política y los procesos de paz con las guerrillas. Al no reconocérsele legitimidad al Estado, los anhelos reformistas quedan atrapados por una retórica que niega las bases mismas del reformismo y tiende por ello a minar las instituciones democráticas. A su turno, en la búsqueda de justificaciones para negociar con los grupos armados ilegales suele acudirse erradamente al discurso de la legitimidad. Sin embargo, como lo ha advertido el historiador Jorge Orlando Melo, con la guerrilla se negocia "porque tiene poder, no porque tenga legitimidad. Este puede ser un matiz leguleyo, pero sólo entre nosotros la diferencia entre un poder basado en la ciudadanía y un poder basado en las armas parece asunto marginal y leguleyo." (Posada Carbó, 2003a: 15).

\section{El "conflicto" colombiano hoy: diversidad de narrativas y representaciones}

Moncayo \& Pizarro Leóngómez (2015), en su calidad de relatores del informe, consideran que desde 1958 hasta la organización de la "Comi- 
sión Histórica del Conflicto y sus Víctimas" (CHCV), por parte de la Mesa de Conversaciones de La Habana en el 2012, funcionaron en Colombia numerosas comisiones de estudio e investigación sobre el fenómeno de la violencia (doce de carácter nacional y tres locales), así como algunas comisiones extrajudiciales para casos específicos, creadas por decisiones gubernamentales, sin que ninguna de ellas haya tenido el carácter de una las conversaciones de paz. La Comisión fue conformada por doce expertos y dos relatores, con la misión de producir un informe sobre los orígenes y las múltiples causas del conflicto, los principales factores y condiciones que han facilitado o contribuido a su persistencia, y los efectos e impactos más notorios del mismo sobre la población.

El informe denominado "Contribución al entendimiento del conflicto armado en Colombia. Introducción conjunta a las dos relatorías de la Comisión Histórica del Conflicto y sus Víctimas", integrado por los ensayos de los expertos y dos relatorías, como se muestra en el Cuadro 2, se definió por la Mesa de Diálogos, como un "insumo fundamental para la comprensión de la complejidad del conflicto y de las responsabilidades de quienes hayan participado o tenido incidencia en el mismo, y para el esclarecimiento de la verdad".

Es importante anotar que dadas las características de las reflexiones producidas por los expertos, que respondieron a la misión encomendada a partir de sus personales perspectivas teóricas, con formas de abordaje muy especificas y de diferente alcance, los relatores acordaron producir también en forma separada sus respectivos informes, en los cuales, como se podrá aprecia en el documento, además, se evidencia la riqueza ofrecida por la pluralidad de visiones. Su redacción final tuvo en cuenta, en cuanto fue posible, las observaciones y sugerencias formuladas por los consultores.

Aunque los ensayos coinciden en líneas generales en que el conflicto no comenzó ni se agota en las Farc, son tan diversos que aún más que un relato plural son 14 visiones muy heterogéneas. El documento consta de aproximadamente 200 páginas (relatorías) y más 600 de los 12 informes presentados. El contenido del informe ofrece entonces las diversas versiones sobre las causas, la dinámica y las justificaciones o no del conflicto colombiano

En este contexto, este informe contiene 14 visiones narrativas, según los siguientes criterios básicos y generales planteados como interrogantes: (1) ¿Cuándo empezó el conflicto? (2) ¿Cuáles son sus causas funda- 
mentales? (3) Para qué la contrainsurgencia como política de Estado? (4) ¿Es justo el origen del conflicto? ¿Cuál ha sido el papel del narcotráfico? (5) ¿Sirvió en Frente Nacional?

Cuadro 1. Corpus documental complementario: catorce (14) ensayos: "Contribución al entendimiento del conflicto armado en Colombia. Comisión Histórica del Conflicto y sus Víctimas Febrero de 2015".

\begin{tabular}{|c|c|c|}
\hline Número & Autor & Título \\
\hline 1 & Sergio De Zubiría Samper & $\begin{array}{l}\text { "Dimensiones políticas y culturales } \\
\text { en el conflicto colombiano" }\end{array}$ \\
\hline 2 & Gustavo Duncan Cruz & "Exclusión, insurrección y crimen" \\
\hline 3 & Jairo Hernando Estrada Álvarez & $\begin{array}{l}\text { "Acumulación capitalista, } \\
\text { dominación de clase y rebelión } \\
\text { armada" }\end{array}$ \\
\hline 4 & Darío Fajardo Montaña & $\begin{array}{l}\text { "Estudio sobre los orígenes del con- } \\
\text { flicto social armado, razones para } \\
\text { su persistencia y sus efectos más } \\
\text { profundos en la sociedad colom- } \\
\text { biana" }\end{array}$ \\
\hline 5 & Javier Giraldo Moreno S.J. & $\begin{array}{l}\text { "Aportes sobre el origen del conflic- } \\
\text { to armado en Colombia, su persis- } \\
\text { tencia y sus impactos" }\end{array}$ \\
\hline 6 & Jorge Giraldo Ramírez & "Política y guerra sin compasión" \\
\hline 7 & Francisco Gutiérrez Sanín & ¿Una historia simple?" \\
\hline 8 & Alfredo Molano Bravo & $\begin{array}{l}\text { "Fragmentos de la historia del con- } \\
\text { flicto armado (1920-2010)" }\end{array}$ \\
\hline 9 & Víctor Manuel Moncayo Cruz & $\begin{array}{l}\text { Relatoría. "Hacia la verdad del } \\
\text { conflicto: insurgencia guerrillera y } \\
\text { orden social vigente" }\end{array}$ \\
\hline 10 & Daniel Pécaut & $\begin{array}{l}\text { "Un conflicto armado al servicio } \\
\text { del status quo social y político" }\end{array}$ \\
\hline 11 & Eduardo Pizarro Leongómez & $\begin{array}{l}\text { Relatoría. "Una lectura múltiple y } \\
\text { pluralista de la historia" }\end{array}$ \\
\hline 12 & Vicente Torrijos Rivera & $\begin{array}{l}\text { "Cartografía del conflicto: pautas } \\
\text { interpretativas sobre la evolución } \\
\text { del conflicto irregular colombiano" }\end{array}$ \\
\hline 13 & Renán Vega Cantor & $\begin{array}{l}\text { "Injerencia de los Estados Unidos, } \\
\text { contrainsurgencia y terrorismo de } \\
\text { Estado" }\end{array}$ \\
\hline 14 & María Emma Wills Obregón & $\begin{array}{l}\text { "Los tres nudos de la guerra colom } \\
\text { biana" }\end{array}$ \\
\hline
\end{tabular}

Fuente: Elaboración del autor 
El 11 de febrero de 2016, se presentó en La Habana-Cuba, el resultado de la Comisión Histórica del Conflicto. Un extenso y complejo documento que mediante el trabajo de dos relatorías condensaron 12 informes elaborados por académicos nombrados por cada lado de la mesa. Como lo plantea Lewin (2016), aunque los ensayos coinciden en líneas generales en que el conflicto no comenzó ni se agota en las Farc, son tan diversos que aún más que un relato plural son 14 visiones muy heterogéneas. Éstas, según él, son las diversas versiones sobre las causas, la dinámica y las justificaciones o no de la guerra colombiana:

Cuadro 2. Coincidencias y divergencias de los catorce (14) ensayos: "Contribución al entendimiento del conflicto armado en Colombia. Comisión Histórica del Conflicto y sus Víctimas Febrero de 2015".

\begin{tabular}{lll}
\hline $\begin{array}{l}\text { No Cuestiona- } \\
\text { mientos }\end{array}$ & Respuestas \\
\hline 1 Cuando \\
empezó el \\
conflicto & En los años 20 del siglo XX \\
& hasta entonces prácticamente no habían existido dada la es- \\
& casa población y las enormes extensiones de baldíos y otras \\
& tierras improductivas. Ese conflicto, para varios comisiona- \\
& dos como Darío Fajardo, Javier Giraldo, Julio Estrada y Ser- \\
& gio de Zubiría, fue el detonante de la lucha. "En los procesos \\
& acaecidos a partir de la década de 1920 se encuentran los \\
& orígenes del actual conflicto social y armado." escribe Es- \\
& trada. \\
& Con La Violencia \\
& Para Alfredo Molano, la situación es tan clara que la primera \\
& frase de su ensayo es "El conflicto armado comienza con la \\
& Violencia." Con él coincide Daniel Pécaut. \\
& Durante el Frente Nacional \\
& Varios comisionados ven unas diferencias fundamentales en- \\
& tre la Violencia clásica y con mayúscula de la que violencia \\
& que empezó a inicios de los año sesenta. "Ambas oleadas \\
& están orgánicamente conectadas (es decir, la Violencia y el \\
& período de la guerra contra-insurgente) y muestran muchas \\
& continuidades (...), son distintas en sus protagonistas, prin- \\
& cipales motivos y lógicas subyacentes" dice Francisco Gutié- \\
& rrez Sanín. \\
& Gustavo Duncan es quien ubica ese origen en una fecha más \\
& tardía, a fines del Frente Nacional: "A mediados de los se- \\
& tentas cuando se cuece la violencia que va a sacudir en las \\
& últimas décadas a Colombia, los problemas de exclusión es- \\
& taban presentes a lo largo de todo el país. " \\
&
\end{tabular}


El conflicto social y político colombiano en los libros de texto escolar de ciencias sociales: representación, diversidad y narrativa

Miguel Ángel Gómez Mendoza y María Victoria Alzate Piedrahita

\begin{tabular}{|c|c|c|}
\hline $\mathbf{N}^{0}$ & $\begin{array}{l}\text { Cuestiona- } \\
\text { mientos }\end{array}$ & Respuestas \\
\hline 2 & $\begin{array}{l}\text { Cuáles } \\
\text { son sus } \\
\text { grandes } \\
\text { causas }\end{array}$ & 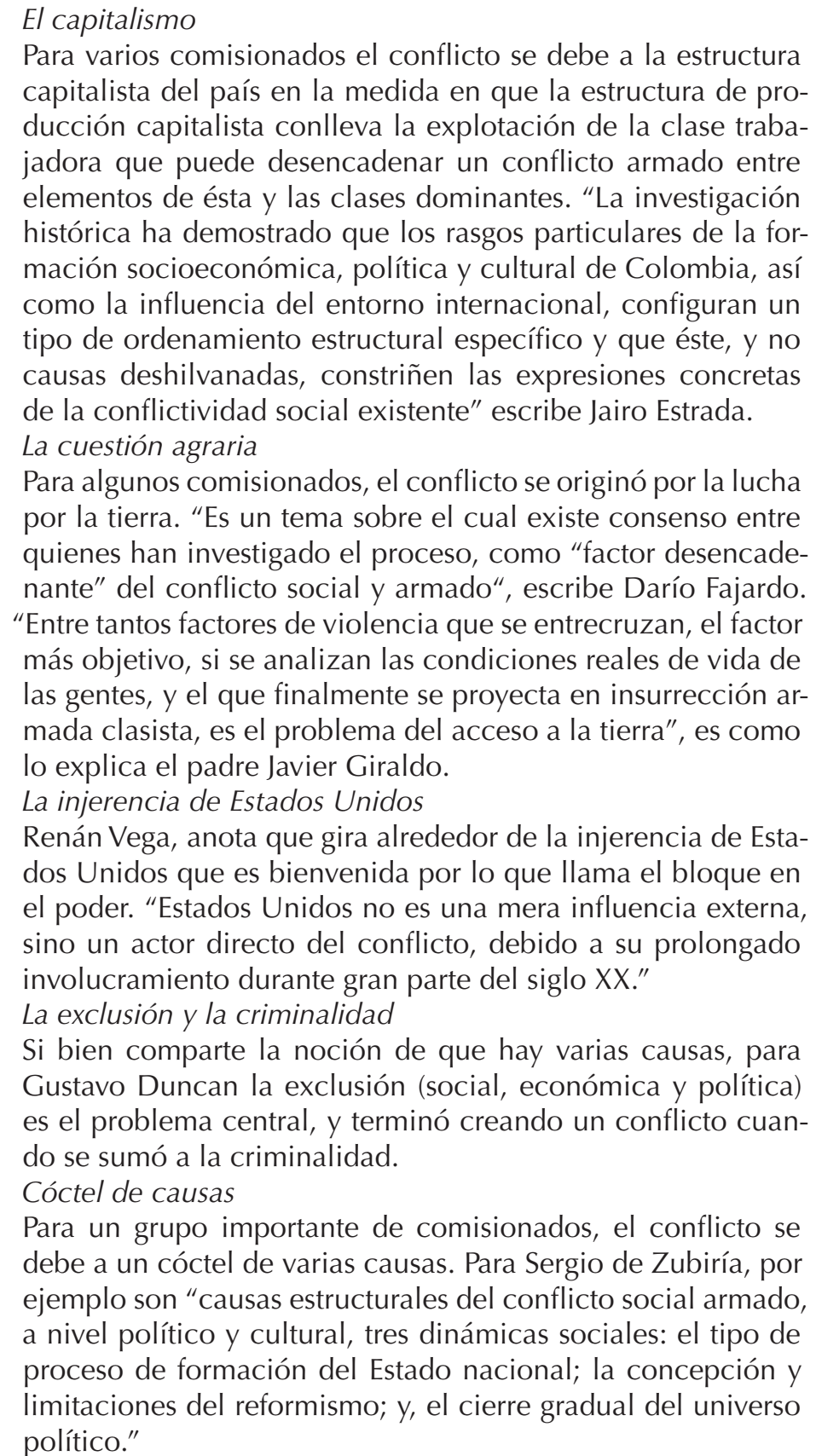 \\
\hline
\end{tabular}


El conflicto social y político colombiano en los libros de texto escolar de ciencias sociales: representación, diversidad y narrativa Miguel Ángel Gómez Mendoza y María Victoria Alzate Piedrahita

\begin{tabular}{|c|c|c|}
\hline $\mathbf{N}^{\mathbf{0}}$ & $\begin{array}{l}\text { Cuestiona- } \\
\text { mientos }\end{array}$ & Respuestas \\
\hline 3 & $\begin{array}{l}\text { Para qué } \\
\text { la contra- } \\
\text { insurgen- } \\
\text { cia }\end{array}$ & 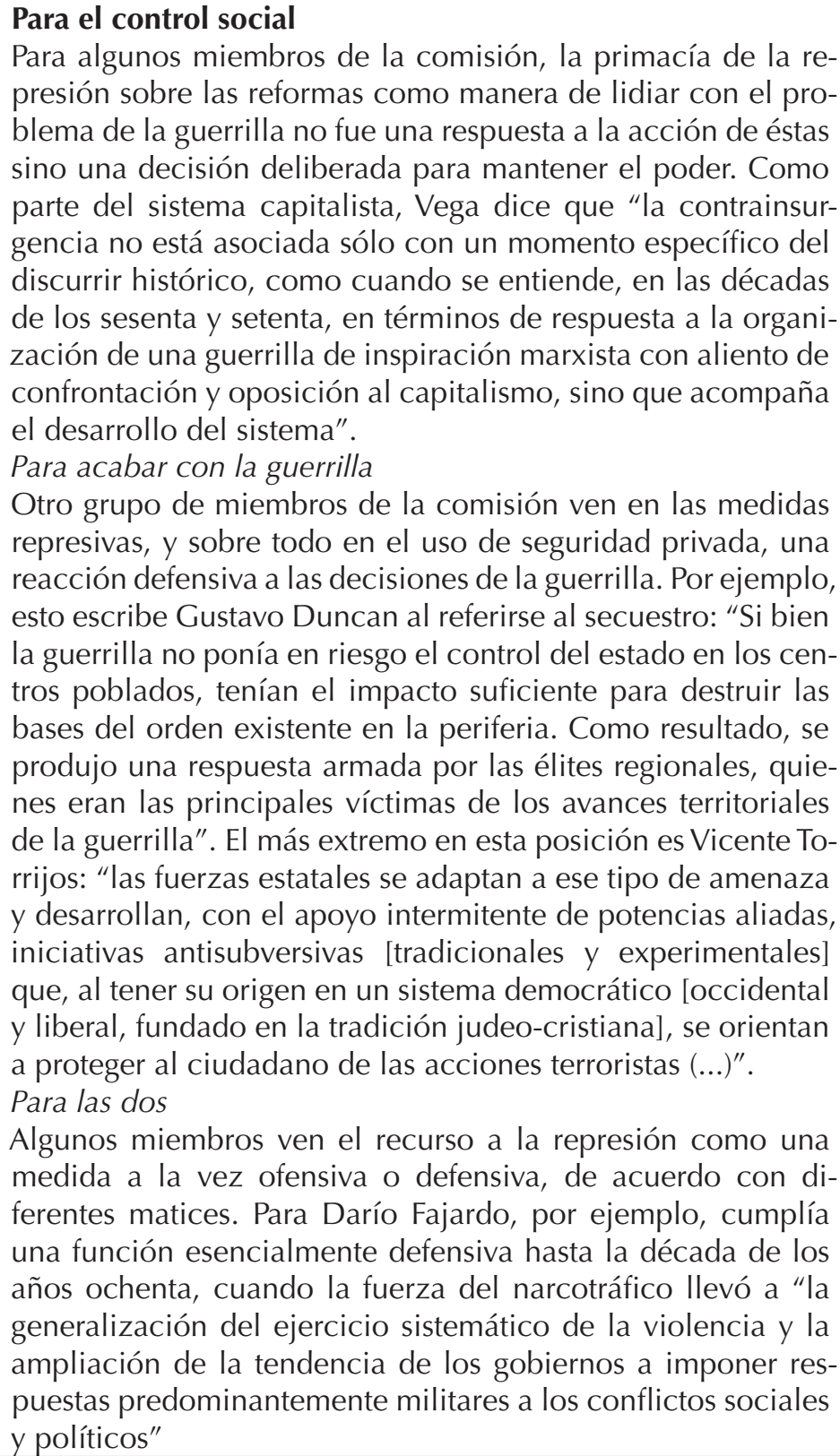 \\
\hline
\end{tabular}


El conflicto social y político colombiano en los libros de texto escolar de ciencias sociales: representación, diversidad y narrativa

Miguel Ángel Gómez Mendoza y María Victoria Alzate Piedrahita

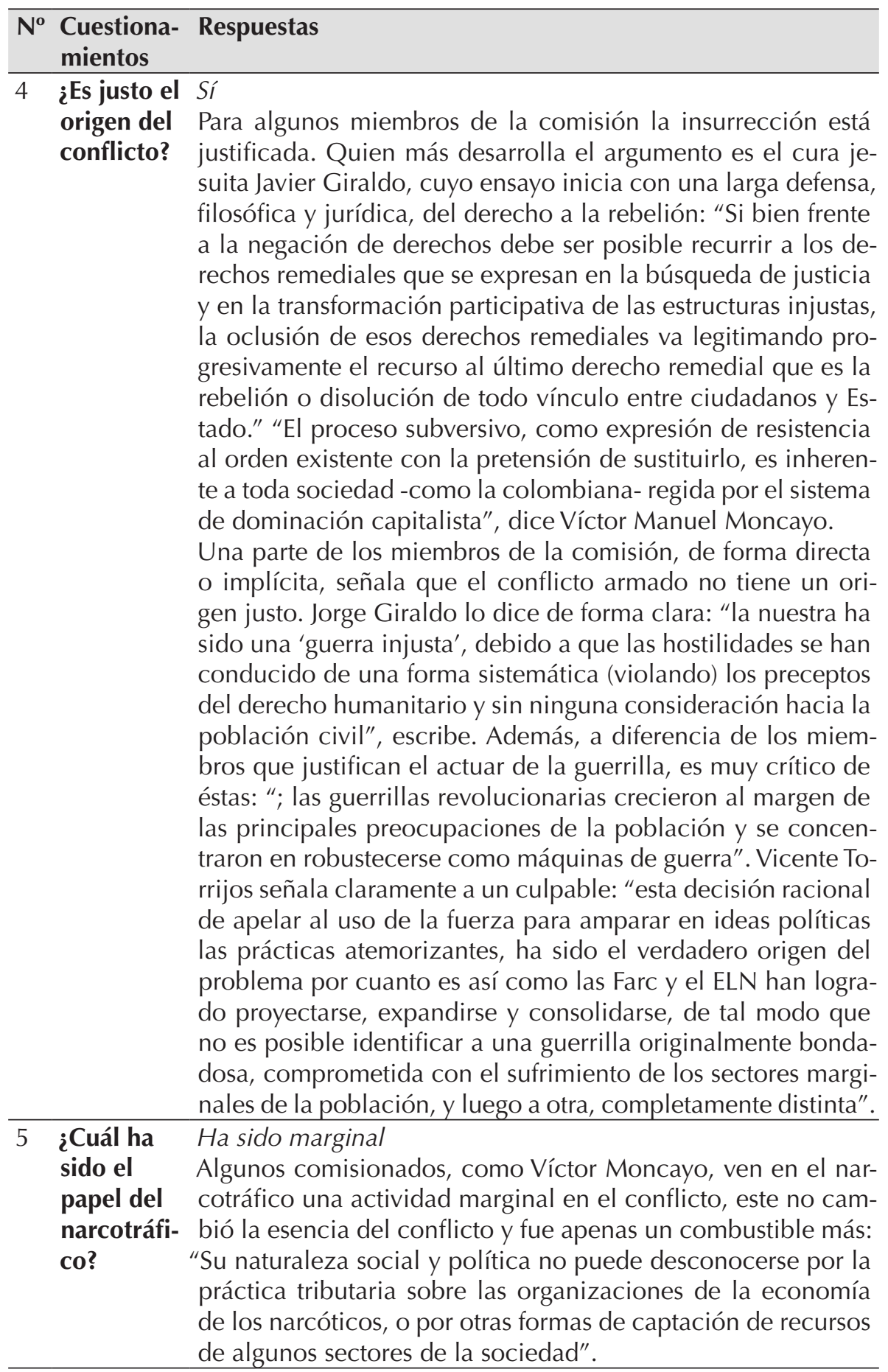


El conflicto social y político colombiano en los libros de texto escolar de ciencias sociales: representación, diversidad y narrativa Miguel Ángel Gómez Mendoza y María Victoria Alzate Piedrahita

\section{Cuestiona- Respuestas mientos}

Ha sido importante

Otros ven en el narcotráfico un factor relevante, aunque no central en la evolución de la guerra. "Con el empresariado de la cocaína se produjo una ampliación del bloque de poder contrainsurgente. Esta facción ha desempeñado un papel significativo en su propósito de preservación sistémica. Su incidencia, tanto sobre la trayectoria de la formación socioeconómica como sobre el curso de la guerra a partir de la década de 1980 ha sido indiscutible", explica Jairo Estrada. "La vinculación de Colombia con la economía internacional del narcotráfico marca una fase ascendente en el conflicto social y armado que afecta al país" escribe Darío Fajardo. "La fusión progresiva de los cocaleros más poderosos o narcotraficantes con el paramilitarismo, hace que la guerra asuma contornos más dramáticos" dice el padre Javier Giraldo.

Ha sido decisivo

Para otro grupo, el narcotráfico juega un papel fundamental en el conflicto, especialmente desde los años ochenta. Así lo explica Gustavo Duncan: "En cierto momento, muchos de los objetivos y motivaciones iniciales de los actores involucrados cambiaron a medida que se replanteaban sus posibilidades de acuerdo a los resultados de la guerra. El narcotráfico fue crucial para perfilar estos cambios porque generó una economía política que permitía sostener el conflicto de manera indefinida". Para Jorge Giraldo es el elemento que explica el cambio en la violencia desde inicios de la década de los años ochenta: "en tres lustros (1983-1998) en Colombia se acumularon diferentes violencias y se organizaron alrededor de la actividad avasallante de los narcotraficantes y de su ataque violento contra las instituciones del Estado", dice. Daniel Pécaut comparte esa postura: "es difícil negar que el narcotráfico tiene una responsabilidad fundamental en en el fortalecimiento de todos los protagonistas que intervienen en el conflicto armado, los narcotraficantes en primer lugar, pero también las guerrillas, los paramilitares, las bandas de criminalidad organizada."

6 ¿Sirvió Tuvo logros rescatables

el frente

nacional? Para varios de los miembros de la Comisión, el Frente Nacional es rescatable: " fue más que una dictadura disfrazada pero menos que una democracia garantista", en palabras de María Emma Wills, "en las elecciones para Congreso participaron 


\section{No Cuestiona- Respuestas mientos \\ no sólo corrientes pro-Frente Nacional", que se logró detener la violencia y salir de la dictadura y que hubo un gran avance en la movilización social y el sistema educativo. Para Eduardo Pizarro, de hecho tuvo logros significativos: "no solamente en el plano de la participación política, la movilización social, la cultura y la educación hubo resultados relevantes. En el terreno de la transición de la guerra a la paz también se al- canzaron éxitos significativos", explica. Un tercer ejemplo es el de Jorge Giraldo, quien argumenta que "el Frente Nacional logró normalizar el país y hacer funcionales las instituciones de gobierno aunque no pudo superar los atrasos en la cons- trucción estatal y careció de voluntad y medios para entender y enfrentar el nuevo desafío violento". \\ Bloqueó la política \\ El enfoque de otro grupo de comisionados es que el acuerdo bipartidista de 1957 trajo unas consecuencias nefastas para el funcionamiento del Estado y la sociedad colombiana. Re- nán Vega dice que "durante el Frente Nacional se establece un pacto bipartidista excluyente y antidemocrático que para mantener a raya la inconformidad popular recurre a la repre- sión, al Estado de Sitio y a la contrainsurgencia"; Sergio de Zubiría, que "En esta etapa se consolida un Estado 'capturado', 'particularista' o 'privatizado'".}

Fuente: Elaboración a partir de Lewin, J.E. Coincidencias y divergencias de los 14 relatos sobre la guerra. Ver: http://lasillavacia.com/print/49558\# Consulta realizada el 05-02-2017.

\section{Marco empírico}

\section{Corpus}

Como se muestra en la Tabla 1., se estableció un "corpus" de cuarenta y uno (41) libros de texto escolar mediante un criterio de catalogación básica, que resulta de una primera revisión o lectura exploratoria de ciento veinte (120) libros de texto escolar según editoriales representativas, grados escolares $\left(6^{\circ}\right.$ a 11$)$ y series editadas para atender los mismos, y criterio temporal contemporáneo (1999-2011). 
Tabla 1. Corpus de libros de texto escolar de ciencias sociales colombianos de la educación básica secundaria y media (1999-2011 Grados $6^{\circ}$ a $\left.11^{\circ}\right)$

\begin{tabular}{|c|c|c|c|c|c|c|}
\hline $\mathrm{N}^{\mathrm{o}}$ & Texto & Editor & Grado & Año & Autores & $\begin{array}{l}\text { Pp. } \\
\text { de } \\
\text { pág }\end{array}$ \\
\hline 1 & $\begin{array}{l}\text { Contextos So- } \\
\text { ciales } 7\end{array}$ & Santillana & $7^{\circ}$ & 2004 & Rueda, Wilson Paul. Tanacs, Erika. & 256 \\
\hline 2 & $\begin{array}{l}\text { Contextos So- } \\
\text { ciales } 8\end{array}$ & Santillana & $8^{\circ}$ & 2004 & $\begin{array}{c}\text { Borja Gómez, Jaime Humberto. } \\
\text { Rueda, Wilson Paul. Lavacude } \\
\text { Parra, Kenny }\end{array}$ & 256 \\
\hline 3 & $\begin{array}{l}\text { Contextos So- } \\
\text { ciales } 9\end{array}$ & Santillana & $9^{\circ}$ & 2004 & $\begin{array}{c}\text { Ortíz Jiménez, José Guillermo. } \\
\text { Rueda, Wilson Paul. Tanacs, Erika. }\end{array}$ & 272 \\
\hline 4 & $\begin{array}{l}\text { Nuevo Identida- } \\
\text { des } 6\end{array}$ & Norma & $6^{\circ}$ & 2005 & $\begin{array}{c}\text { Claudia, Rodríguez, Óscar Pulido, } \\
\text { Álvaro Chaustre, Vladimir Melo, } \\
\text { Javier Machicado }\end{array}$ & 248 \\
\hline 5 & $\begin{array}{l}\text { Nuevo identida- } \\
\text { des } 6 \text { Libro de } \\
\text { actividades }\end{array}$ & Norma & $6^{\circ}$ & 2005 & $\begin{array}{c}\text { Claudia, Rodríguez, Óscar Pulido, } \\
\text { Álvaro Chaustre, Vladimir Melo, } \\
\text { Javier Machicado Machicado }\end{array}$ & 248 \\
\hline 6 & $\begin{array}{l}\text { Nuevo Identida- } \\
\text { des } 9\end{array}$ & Norma & $9^{\circ}$ & 2005 & $\begin{array}{c}\text { Andrés Gordillo, Néstor Miranda, } \\
\text { Nohra León, Germán Narváez, } \\
\text { Vladimir Melo, }\end{array}$ & 264 \\
\hline 7 & Ejes sociales 6 & $\begin{array}{l}\text { Educar } \\
\text { Editores }\end{array}$ & $6^{\circ}$ & 2007 & $\begin{array}{c}\text { Maria Carlota Ortiz Rodríguez, } \\
\text { Germán Antonio Granada Osorio }\end{array}$ & 232 \\
\hline 8 & Ejes sociales 7 & $\begin{array}{l}\text { Educar } \\
\text { Editores }\end{array}$ & $7^{\circ}$ & 2007 & $\begin{array}{c}\text { Maria Carlota Ortiz Rodríguez, } \\
\text { Germán Antonio Granada Osorio }\end{array}$ & 224 \\
\hline 9 & Ejes sociales 8 & $\begin{array}{l}\text { Educar } \\
\text { Editores }\end{array}$ & $8^{\circ}$ & 2007 & $\begin{array}{c}\text { Maria Carlota Ortiz Rodríguez, } \\
\text { Germán Antonio Granada Osorio }\end{array}$ & 200 \\
\hline 10 & $\begin{array}{l}\text { Navegantes } \\
\text { Sociales } 6\end{array}$ & Norma & $6^{\circ}$ & 2008 & $\begin{array}{c}\text { Germán Narváez Bravo, Ricardo } \\
\text { Vargas Ramírez, Heublyn Castro, } \\
\text { Camilo Bonilla. }\end{array}$ & 152 \\
\hline 11 & $\begin{array}{l}\text { Navegantes } \\
\text { Sociales } 9\end{array}$ & Norma & $9^{\circ}$ & 2008 & $\begin{array}{c}\text { Germán Narváez Bravo, José } \\
\text { Vicente Feo, Franz Hensel Riveros, } \\
\text { Óscar Linares }\end{array}$ & 160 \\
\hline 12 & Socialmente 8 & $\begin{array}{l}\text { Voluntad } \\
\text { S.A. }\end{array}$ & $8^{\circ}$ & 2008 & $\begin{array}{c}\text { Daniel Felipe Arias Escobar, Ma- } \\
\text { nuel Andrés Garcia Escolar, Nelsi } \\
\text { Guevara Izquierdo }\end{array}$ & 208 \\
\hline 13 & $\begin{array}{l}\text { Vivencias } 7 \mathrm{Li}- \\
\text { bro de trabajo }\end{array}$ & $\begin{array}{l}\text { Voluntad } \\
\text { S.A. }\end{array}$ & $7^{\circ}$ & 2009 & $\begin{array}{c}\text { Fabio Sánchez Calderón, Jenny } \\
\text { Rocío Jiménez Monguí, Nubia } \\
\text { Moreno Lache }\end{array}$ & 208 \\
\hline 14 & Vivencias 8 & $\begin{array}{c}\text { Voluntad } \\
\text { S.A. }\end{array}$ & $8^{\circ}$ & 2009 & $\begin{array}{c}\text { Juana María Rubio Fernández, } \\
\text { Daniel Felipe Arias Escobar }\end{array}$ & 208 \\
\hline 15 & $\begin{array}{l}\text { Vivencias } 8 \\
\text { Libro de activi- } \\
\text { dades }\end{array}$ & $\begin{array}{l}\text { Voluntad } \\
\text { S.A. }\end{array}$ & $8^{\circ}$ & 2009 & $\begin{array}{c}\text { Juana María Rubio Fernández, } \\
\text { Daniel Felipe Arias Escobar }\end{array}$ & 208 \\
\hline
\end{tabular}


El conflicto social y político colombiano en los libros de texto escolar de ciencias sociales: representación, diversidad y narrativa

Miguel Ángel Gómez Mendoza y María Victoria Alzate Piedrahita

\begin{tabular}{|c|c|c|c|c|c|c|}
\hline $\mathrm{N}^{\mathrm{o}}$ & Texto & Editor & Grado & Año & Autores & $\begin{array}{l}\text { Pp. } \\
\text { de } \\
\text { pág }\end{array}$ \\
\hline 16 & Vivencias 9 & $\begin{array}{l}\text { Voluntad } \\
\text { S.A. }\end{array}$ & $9^{\circ}$ & 2009 & $\begin{array}{c}\text { Tania Milena Lizarazo Moreno, } \\
\text { Natalia Castañeda Angarita }\end{array}$ & 208 \\
\hline 17 & $\begin{array}{l}\text { Vivencias } 9 \\
\text { Libro de activi- } \\
\text { dades }\end{array}$ & $\begin{array}{l}\text { Voluntad } \\
\text { S.A. }\end{array}$ & $9^{\circ}$ & 2009 & $\begin{array}{c}\text { Tania Milena Lizarazo Moreno, } \\
\text { Natalia Castañeda Angarita }\end{array}$ & 208 \\
\hline 18 & $\begin{array}{l}\text { Viajeros Socia- } \\
\text { les } 6\end{array}$ & Norma & $6^{\circ}$ & 2009 & $\begin{array}{c}\text { Germán Narváez Bravo, Ricardo } \\
\text { Vargas Ramírez, Claudia Patricia } \\
\text { Parra. } \\
\end{array}$ & 240 \\
\hline 19 & $\begin{array}{l}\text { Viajeros Socia- } \\
\text { les } 9\end{array}$ & Norma & $9^{\circ}$ & 2009 & $\begin{array}{c}\text { Fabio Sánchez Calderón, José } \\
\text { Feo Basto, Franz Riveros, Óscar } \\
\text { Linares Londoño }\end{array}$ & 248 \\
\hline 20 & $\begin{array}{l}\text { Viajeros Socia- } \\
\text { les } 9 \text { Libro de } \\
\text { actividades } \\
\end{array}$ & Norma & $9^{\circ}$ & 2009 & $\begin{array}{c}\text { Fabio Sánchez Calderón, José } \\
\text { Feo Basto, Franz Riveros, Óscar } \\
\text { Linares Londoño }\end{array}$ & 248 \\
\hline 21 & $\begin{array}{l}\text { Estrategias en } \\
\text { Ciencias Socia- } \\
\text { les } 7\end{array}$ & $\begin{array}{l}\text { Libros y } \\
\text { Libros }\end{array}$ & $7^{\circ}$ & 2010 & $\begin{array}{c}\text { Juan Cristobal de Jesus Restrepo, } \\
\text { José Guillermo Ortiz }\end{array}$ & 272 \\
\hline 22 & $\begin{array}{l}\text { Estrategias en } \\
\text { Ciencias Socia- } \\
\text { les } 9\end{array}$ & $\begin{array}{l}\text { Libros y } \\
\text { Libros }\end{array}$ & $9^{\circ}$ & 2010 & $\begin{array}{l}\text { Miguel Gil Fonseca, José Guiller- } \\
\text { mo Ortiz }\end{array}$ & 288 \\
\hline 23 & $\begin{array}{l}\text { Estrategias en } \\
\text { Ciencias Socia- } \\
\text { les } 10\end{array}$ & $\begin{array}{l}\text { Libros y } \\
\text { Libros }\end{array}$ & $10^{\circ}$ & 2010 & $\begin{array}{c}\text { Juan Cristobal de Jesus Restrepo, } \\
\text { José Guillermo Ortiz }\end{array}$ & 231 \\
\hline 24 & $\begin{array}{l}\text { Estrategias en } \\
\text { Ciencias Socia- } \\
\text { les } 11\end{array}$ & $\begin{array}{l}\text { Libros y } \\
\text { Libros }\end{array}$ & $11^{\circ}$ & 2010 & Juan Cristobal de Jesus Restrepo & 216 \\
\hline 25 & $\begin{array}{l}\text { Nuevo Latitudes } \\
\text { Geografía Hu- } \\
\text { mana General y } \\
\text { de Colombia }\end{array}$ & Norma & $9^{\circ}$ & 2009 & Fabio Vladimir Sánchez Calderón & 256 \\
\hline 26 & $\begin{array}{l}\text { Hipertexto } \\
\text { Sociales } 8\end{array}$ & Santillana & $8^{\circ}$ & 2010 & $\begin{array}{c}\text { Boris Caballero, Jorge Cote, He- } \\
\text { Ilen Cristancho, Arnovy Fajardo, } \\
\text { Carlos Maldonado, }\end{array}$ & 272 \\
\hline 27 & $\begin{array}{l}\text { Hipertexto } \\
\text { Sociales } 9\end{array}$ & Santillana & $9^{\circ}$ & 2010 & $\begin{array}{c}\text { Carlos Maldonado, Fabio Prieto, } \\
\text { Jorge Cote Rodriguez, Fabio Co- } \\
\text { bos Pinzón }\end{array}$ & 288 \\
\hline 28 & $\begin{array}{l}\text { Hipertexto } \\
\text { Sociales } 11 \\
\end{array}$ & Santillana & $11^{\circ}$ & 2010 & $\begin{array}{l}\text { José Guillermo Ortiz Jiménez, } \\
\text { Luis Eduardo Galindo Neira }\end{array}$ & 208 \\
\hline 29 & $\begin{array}{l}\text { Zonactiva Socia- } \\
\text { les } 8\end{array}$ & Norma & $8^{\circ}$ & 2011 & $\begin{array}{c}\text { Melo, Claudia Rodríguez Tinjacá, } \\
\text { Camilo Páez, Mauricio Estévez, } \\
\text { Camilo Moncada }\end{array}$ & 288 \\
\hline
\end{tabular}


El conflicto social y político colombiano en los libros de texto escolar de ciencias sociales: representación, diversidad y narrativa Miguel Ángel Gómez Mendoza y María Victoria Alzate Piedrahita

\begin{tabular}{|c|c|c|c|c|c|c|}
\hline & Texto & Editor & Grado & Año & Autores & $\begin{array}{l}\text { Pp. } \\
\text { de } \\
\text { pág }\end{array}$ \\
\hline 30 & $\begin{array}{l}\text { Zonactiva Socia- } \\
\text { les } 9\end{array}$ & Norma & $9^{\circ}$ & 2011 & $\begin{array}{c}\text { Fabio Sánchez, Olga Estévez, } \\
\text { Liliana Morales, Yairsiño Oviedo, } \\
\text { Claudia Rodríguez, }\end{array}$ & 288 \\
\hline 31 & $\begin{array}{l}\text { Zonactiva Socia- } \\
\text { les } 9 \text { Guía del } \\
\text { educador }\end{array}$ & Norma & $9^{\circ}$ & 2011 & $\begin{array}{c}\text { Fabio Sánchez, Olga Estévez, } \\
\text { Liliana Morales, Yairsiño Oviedo, } \\
\text { Claudia Rodríguez, }\end{array}$ & 288 \\
\hline 31 & $\begin{array}{l}\text { Zonactiva Socia- } \\
\text { les } 10\end{array}$ & Norma & $10^{\circ}$ & 2010 & $\begin{array}{l}\text { Fabio Sánchez, Diana Rojas, } \\
\text { Yairsiño Oviedo, Nohora León, } \\
\text { Angélica Nieto. }\end{array}$ & 200 \\
\hline 33 & $\begin{array}{l}\text { Zonactiva Socia- } \\
\text { les } 10 \text { Guía del } \\
\text { educador }\end{array}$ & Norma & $10^{\circ}$ & 2011 & $\begin{array}{l}\text { Fabio Sánchez, Diana Rojas, } \\
\text { Yairsiño Oviedo, Nohora León, } \\
\text { Angélica Nieto. }\end{array}$ & 200 \\
\hline 34 & $\begin{array}{l}\text { Zonactiva Socia- } \\
\text { les } 11 \text { Guía del } \\
\text { educador }\end{array}$ & Norma & $11^{\circ}$ & 2011 & $\begin{array}{c}\text { Vladimir Melo, Humberto Pérez, } \\
\text { Nohora León Rodríguez, Luz } \\
\text { María Gallo. } \\
\end{array}$ & 200 \\
\hline 35 & $\begin{array}{l}\text { Ciencias Socia- } \\
\text { les } 9\end{array}$ & Santillana & $9^{\circ}$ & 1999 & Kenny Lavacude Parra & 242 \\
\hline 36 & Identidades 7 & Norma & $7^{\circ}$ & 2004 & Mauricio Milazzo & 256 \\
\hline 37 & Identidades 9 & Norma & $9^{\circ}$ & 2004 & $\begin{array}{c}\text { Andrés Gordillo, Néstor Miranda, } \\
\text { Nohra León, Germán Narváez, } \\
\text { Vladimir Melo }\end{array}$ & 264 \\
\hline 38 & $\begin{array}{l}\text { Identidades } 9 \\
\text { Libro de activi- } \\
\text { dades }\end{array}$ & Norma & $9^{\circ}$ & 2004 & $\begin{array}{l}\text { Nohora leon, Andrés Gordillo, } \\
\text { Néstor Miranda, Nohra León, } \\
\text { Vladimir Melo, }\end{array}$ & 272 \\
\hline 39 & Identidades 10 & Norma & $10^{\circ}$ & 2004 & $\begin{array}{l}\text { Vladimir Melo, Javier Machicado, } \\
\text { Néstor Miranda, Andrés Gordillo, } \\
\text { Sonia Mora, }\end{array}$ & 296 \\
\hline 40 & Identidades 11 & Norma & $11^{\circ}$ & 2004 & $\begin{array}{c}\text { Vladimir Melo, Diana Rojas, So- } \\
\text { nia Mora, Diego Pineda, Ricardo } \\
\text { Arias, Franz Riveros }\end{array}$ & 296 \\
\hline 41 & $\begin{array}{l}\text { Ciencias Socia- } \\
\text { les } 7\end{array}$ & $\begin{array}{l}\text { Educar } \\
\text { Editores }\end{array}$ & $7^{\circ}$ & 2005 & Germán Antonio Granada Osorio & 176 \\
\hline
\end{tabular}

\section{Metodología}

Fase 1. Realización de un estado de la cuestión sobre el "conflicto" en Colombia a través de la revisión de un "corpus" documental especializado ensayos sobre el conflicto y la violencia en Colombia: "Contribución 
al entendimiento del conflicto armado en Colombia. Comisión Histórica del Conflicto y sus Víctimas Febrero de 2015", para establecer una "tipología" y categorización de los elementos históricos, políticos, económicos y culturales del denominado "conflicto" colombiano

Fase 2. Evaluación del "corpus" de libros de texto escolar colombianos establecido para el estudio y del "corpus" documental especializado.

Procedimiento de recolección y organización de la información. Aplicación de fichas de catalogación documental y de registro de contenido. Mapas" de catalogación bibliográfica y documental

Procedimientos de análisis. Análisis conceptual y elaboración de "tipologías" conceptuales disciplinares derivadas de su estudio analítico documental según criterios de exhaustividad, historicidad y actualidad. Cuantitativo: revisión catalográfica del "corpus" de libros de texto del estudio. Cualitativo: elaboración de tipologías sobre el conflicto en la literatura especializada del estudio

\section{Resultados y discusión}

Aquí una cuestión es clave "¿cómo se configura el análisis y la del conflicto social colombiano en los libros de texto escolar de ciencias sociales colombianos?". La indagación científica y académica de los documentos especializados colombianos configura el conflicto social desde diversas perspectivas de estudio que son influenciadas por los múltiples factores y dimensiones en las que se puede abordar este fenómeno. La literatura sobre el tema del conflicto es heterogénea y expresa la complejidad de situaciones y concepciones sobre el tema y el contenido de los libros de texto escolar al respecto no son la excepción. Sin embargo, es posible destacar algunos ejes fundamentales y generales del contenido de los libros de texto que permiten una aproximación a su comprensión, como se muestra de manera esquemática en la Tabla 2. 
Tabla 2. Síntesis de la representación y la narrativa del "Conflicto social y político en los libros de texto escolar de ciencias sociales en la educación secundaria colombiana" (1999-2011)

Tema: La "violencia" de mediados del siglo.

Definición: Choque entre dos partidos políticos tradicionales colombianos, el liberal y conservador, en zonas rurales del país.

\begin{tabular}{|c|c|c|}
\hline \multicolumn{2}{|c|}{ Temporalidad Causas y hechos } & \multirow[t]{2}{*}{ ¿Cómo se enfrento? } \\
\hline 1946-1965 & $\begin{array}{l}\text { - Enfrentamiento entre los partidos. } \\
\text { - Reformas agrarias. } \\
\text { - Lucha por el acceso a ciertos } \\
\text { recursos naturales. } \\
\text { - Tensiones entre los directorios na- } \\
\text { cionales y locales de los partidos. } \\
\text { - Conflictos derivados del problema } \\
\text { de la propiedad de la tierra. }\end{array}$ & \\
\hline $\begin{array}{l}\text { Primera } \\
\text { etapa } \\
1946-1950\end{array}$ & $\begin{array}{l}\text { - Asesinato de Jorge Eliécer Gaitán. } \\
\text { - Polarización del conflicto social. } \\
\text { - Tener el control municipal de los } \\
\text { partidos. }\end{array}$ & $\begin{array}{l}\text { - Los liberales decidie- } \\
\text { ron no ir a mesas de } \\
\text { votaciones. } \\
\text { - Cuadrillasderesistencia. }\end{array}$ \\
\hline $\begin{array}{l}\text { Segunda } \\
\text { etapa } \\
1953\end{array}$ & $\begin{array}{l}\text { - Formación de guerrillas liberales } \\
\text { más consolidadas. } \\
\text { - Choque entre bandas armadas. } \\
\text { - Acciones en contra de la sociedad } \\
\text { civil. } \\
\text { - Fuerzas de seguridad del estado } \\
\text { involucradas con las bandas. }\end{array}$ & $\begin{array}{l}\text { - Control por organis- } \\
\text { mos de seguridad del } \\
\text { estado. }\end{array}$ \\
\hline & $\begin{array}{l}\text { - Procesos de desmovilización de } \\
\text { grupos guerrilleros. } \\
\text { Continuación de la lucha armada } \\
\text { en algunas zonas del país. } \\
\text { - Aquellos cercanos al partido co- } \\
\text { munista, Charro negro y Manuel } \\
\text { Marulanda deciden renunciar a } \\
\text { la amnistía y empezar la coloni- } \\
\text { zación armada por el río Davis,... } \\
\text { hasta el Tolima. }\end{array}$ & \\
\hline
\end{tabular}

Tema: El Frente Nacional.

\begin{tabular}{|c|c|c|}
\hline $\begin{array}{l}\text { Caída de } \\
\text { Rojas Pinilla } \\
1958\end{array}$ & $\begin{array}{l}\text { - Suspensión del diario liberal "El } \\
\text { Tiempo". } \\
\text { - Continúan os ataques de cuadrillas } \\
\text { de bandoleros y la conformación } \\
\text { de la guerrilla comunista. }\end{array}$ & $\begin{array}{l}\text { - Mano dura en zonas } \\
\text { rurales y en las ciuda- } \\
\text { des. } \\
\text { - Operaciones milita- } \\
\text { res y bombardeo de } \\
\text { zonas. }\end{array}$ \\
\hline
\end{tabular}


El conflicto social y político colombiano en los libros de texto escolar de ciencias sociales: representación, diversidad y narrativa

Miguel Ángel Gómez Mendoza y María Victoria Alzate Piedrahita

\begin{tabular}{|c|c|c|}
\hline $\begin{array}{l}\text { El Frente } \\
\text { Nacional y } \\
\text { cuarta etapa } \\
\text { de la violen- } \\
\text { cia partidista } \\
\text { 1958-1974 }\end{array}$ & $\begin{array}{l}\text { - Aparición de grupos guerrilleros } \\
\text { que no se adscribían a ninguno } \\
\text { de los partidos políticos. } \\
\text { - Muchas cuadrillas de "bandoleris- } \\
\text { mo político" empezaron a perder } \\
\text { su carácter partidista y hacer un } \\
\text { transito a grupos armados alinea- } \\
\text { dos en torno a un partido político. }\end{array}$ & $\begin{array}{l}\text { - Proceso de admitía. } \\
\text { zofuerzo militar en } \\
\text { aún existía resistencia } \\
\text { armada. }\end{array}$ \\
\hline \multicolumn{3}{|c|}{ Tema: Colombia desde el final del Frente Nacional hasta la apertura económica. } \\
\hline $\begin{array}{l}\text { Paramilitares } \\
\text { y auto defen- } \\
\text { sas } \\
1982\end{array}$ & $\begin{array}{l}\text { - Surgieron en el marco de la indus- } \\
\text { tria ilegal del narcotráfico y la } \\
\text { actividad minera, especialmente } \\
\text { la esmeralda. } \\
\text { - Surgen grupos como MAS, muerte } \\
\text { a secuestradores y escuadrones } \\
\text { de la muerte, contra grupos de } \\
\text { guerrilleros. } \\
\text { - Los grupos de autodefensas se } \\
\text { organizaron como respuesta de } \\
\text { los ganaderos a las extorsiones de } \\
\text { las FARC y defensa de las propie- } \\
\text { dades adquiridas por los narcotra- } \\
\text { ficantes. }\end{array}$ & $\begin{array}{l}\text { - Ampliación del apara- } \\
\text { to militar } \\
\text { - Creación de bases } \\
\text { sociales de apoyo } \\
\text { - Paso de las "autodefen- } \\
\text { sas" a los "paramilita- } \\
\text { res". }\end{array}$ \\
\hline
\end{tabular}

Tema: La sociedad colombiana desde los años noventa.

Definición: En Colombia el conflicto se produce en el cruce de varias dinámicas y procesos históricos diferentes que se traducen en cambios de control económico y político de los territorios.

\begin{tabular}{|c|c|c|}
\hline $\begin{array}{l}\text { Guerrillas, } \\
\text { zonas de } \\
\text { extradición } \\
\text { y cultivos } \\
\text { ilícitos } \\
1990\end{array}$ & $\begin{array}{l}\text { - Crecimiento de las FARC se acom- } \\
\text { pañó de su progresiva inserción } \\
\text { en el narcotráfico. } \\
\text { - } \text { Los cultivos ilícitos encontraron un } \\
\text { escenario propicio de desarrollo } \\
\text { en zonas de colonización campe- } \\
\text { sina. } \\
\text { - Las FARC controlan el cultivo y } \\
\text { su comercialización...se hacen } \\
\text { cargo del negocio de tráfico y } \\
\text { distribución de cocaína y heroína. } \\
\text { - Estados Unidos, empezó a identifi- } \\
\text { car el conflicto armado con el trá- } \\
\text { fico de drogas y declaró la lucha } \\
\text { contra las drogas como tema de } \\
\text { seguridad nacional. }\end{array}$ & $\begin{array}{l}\text { - Las fuerzas militares } \\
\text { intentan hacer frente } \\
\text { al crecimiento de la } \\
\text { guerrilla. } \\
\text { - Campañas ofensivas } \\
\text { hacia algunos centros } \\
\text { guerrilleros. } \\
\text { - Ataque al comando } \\
\text { central de la FARC. } \\
\text { "Casa Verde". } \\
\text { - El plan Colombia. }\end{array}$ \\
\hline
\end{tabular}


Tema: Formación política. Expresiones del conflicto en Colombia.

Definición: Los argumentos que explican el conflicto u sus manifestaciones violentas en Colombia han puesto de manifiesto algunas constantes como la precaria presencia del Estado en el territorio y su ineficacia para cumplir con sus funciones, la acción de grupos o redes de poder ilegales que compiten entre sí y contra el Estado por el control territorial, las desigualdades entre las regiones y el fortalecimiento de una cultura de violencia que ha impedido abrir un espacio público para solucionar los conflictos y superar la desigualdad socioeconómica de la nación colombiana.

\begin{tabular}{|c|c|c|}
\hline \multicolumn{2}{|c|}{ Temporalidad Causas y hechos } & ¿Cómo se enfrento? \\
\hline $\begin{array}{l}\text { Orígenes de } \\
\text { la violencia } \\
\text { del siglo XX. }\end{array}$ & $\begin{array}{l}\text { - La masacre de la bananeras } 1928 . \\
\text { - El régimen conservador se derrum- } \\
\text { bó y el partido liberal Ilego al } \\
\text { poder a través de el Movimiento } \\
\text { de Concentración Nacional. } \\
\text { - Deterioro del orden público entre } \\
\text { liberales y conservadores. } \\
\text { - Enfrentamientos entre campesinos } \\
\text { - } \text { y terratenientes } \\
\text { - Yensiones entre patronos y obreros } \\
\text { - Jorge Elado y los sindicatos. } \\
\text { 1948. Generó Gaitán, fue asesinado } \\
\text { tazo" }\end{array}$ & $\begin{array}{l}\text { - Reformas bajo el lema } \\
\text { la Revolución en } \\
\text { Marcha. } \\
\text { - Reforma agraria (ley } \\
200 \text { de 1936). } \\
\text { - Limitó el derecho de } \\
\text { propiedad señalando } \\
\text { su función social. } \\
\text { - Extendió el sufragio } \\
\text { - Restauró la libertad } \\
\text { de conciencia y de } \\
\text { enseñanza. }\end{array}$ \\
\hline $\begin{array}{l}\text { Violencia } \\
\text { y guerrillas } \\
\text { liberales } \\
\text { 1948-1953 }\end{array}$ & $\begin{array}{l}\text { - Surgimiento de las guerrillas. } \\
\text { - Se agudizó el enfrentamiento } \\
\text { social hasta el punto de alcanzar } \\
\text { proporciones de guerra en los } \\
\text { campos y las ciudades. } \\
\text { - Los altos dignatarios y trabajadores } \\
\text { liberales del Estado eran despedi- } \\
\text { dos de sus cargos. } \\
\text { - Politización de la Policía Nacional. } \\
\text { - Surgieron grupos como los "chula- } \\
\text { vitas" y los "pájaros". } \\
\text { - El clero católico acusó a los libera- } \\
\text { les de comunistas y enemigos de } \\
\text { la iglesia. } \\
\text { - Algunos guerrilleros no aceptaron } \\
\text { la admitía y se enfrentaron al } \\
\text { Ejercito Nacional. } \\
\text { - Algunos grupos se convirtieron en } \\
\text { bandoleros dedicados al pillaje. }\end{array}$ & $\begin{array}{l}\text { - El estado reprimía } \\
\text { violentamente a sus } \\
\text { adversarios. } \\
\text { - Exilio de importantes } \\
\text { líderes liberales al } \\
\text { extranjero. } \\
\text { - Declaración de ad- } \\
\text { mitía general por el } \\
\text { presidente Rojas. } \\
\text { El Ejercito Nacional } \\
\text { enfrento a los grupos. } \\
\text { - Crea el denominado } \\
\text { Frente Nacional }\end{array}$ \\
\hline
\end{tabular}




\begin{tabular}{|c|c|c|}
\hline & $\begin{array}{l}\text { - Se organizó un movimiento na- } \\
\text { cional para derrocar la dictadura } \\
\text { militar. }\end{array}$ & \\
\hline $\begin{array}{l}\text { El movimien- } \\
\text { to guerrillero } \\
\text { y su trayec- } \\
\text { toria } \\
1958-1974\end{array}$ & $\begin{array}{l}\text { - Se consolida el clientelismo y } \\
\text { burocratización del Estado. } \\
\text { - Problemas en el campo y dificul- } \\
\text { tad para acceder a la propiedad } \\
\text { de la tierra. } \\
\text { - Surgimiento de las FARC, el ELN y } \\
\text { el EPL. } \\
\text { - Construcción de "republicas inde- } \\
\text { pendientes" del partido comunista. } \\
\text { - Estas organizaciones declaran } \\
\text { combinación de la lucha revolu- } \\
\text { cionaria para la toma del poder } \\
\text { en nuestro país. } \\
\text { - Estancamiento de la ofensiva mili- } \\
\text { tar para hacer frente a las agrupa- } \\
\text { ciones campesinas o movimientos } \\
\text { agrarios. } \\
\text { En } 1973 \text { Surgió el movimiento } \\
\text { M-19. }\end{array}$ & $\begin{array}{l}\text { - Ataque del ejercito a } \\
\text { Villarrica (Tolima) } \\
\text { - En } 1964 \text { el Ejercito } \\
\text { atacó a Marquetalia }\end{array}$ \\
\hline $\begin{array}{l}\text { Las guerrillas } \\
\text { en la década } \\
\text { de los } 80\end{array}$ & $\begin{array}{l}\text { - } \text { Recrudecimiento de la actividad } \\
\text { guerrillera, en las ciudades espe- } \\
\text { cialmente del M-19. } \\
\text { - } \text { Robo de más de } 5.000 \text { armas al } \\
\text { Cantón Norte } \\
\text { - } \text { Toma de la embajada de la Repu- } \\
\text { blica Dominicana. } \\
\text { - Expansión de las guerrillas primor- } \\
\text { dialmente de las FARC. } \\
\text { - Surgimiento de la Unión Patriótica } \\
\text { UP. } 1987 . \\
\text { 1985 el M-19 y el EPL dieron por } \\
\text { terminados los diálogos de paz, } \\
\text { por el asesinato de guerrilleros } \\
\text { amnistiados y el incumplimiento } \\
\text { de la tregua. } \\
\text { Toma del Palacio de Justicia donde } \\
\text { murieron } 11 \text { magistrados de la } \\
\text { Corte Suprema del Estado y del } \\
\text { Consejo de Estado, empleados } \\
\text { de la rama judicial y numerosos } \\
\text { visitantes. } 1985 \text {. }\end{array}$ & $\begin{array}{l}\text { - } \text { El estatuto de seguri- } \\
\text { dad } 1978 . \\
\text { - Preeminencia a la ac- } \\
\text { ción militar de } 1.000 \\
\text { hombres pasaron a } \\
15.000 . \\
\text { - Proceso de negocia- } \\
\text { ción política para la } \\
\text { paz con Belisario } \\
\text { Betancur. } \\
\text { - Conformación de la } \\
\text { Comisión de Paz. } \\
\text { - Ley } 35 \text { de } 1982 \text { de } \\
\text { amnistía } \\
\text { - Se levantó el Estado de } \\
\text { Sitio. } \\
\text { - Suscribieron pactos } \\
\text { de cese bilateral del } \\
\text { fuego y tregua con } \\
\text { las FARC, el M-19, el } \\
\text { ELN y dos frentes de } \\
\text { el EPL. 1984. }\end{array}$ \\
\hline
\end{tabular}




\begin{tabular}{|c|c|c|}
\hline & $\begin{array}{l}\text { Continúan emboscadas, asaltos, } \\
\text { secuestros, voladuras de torres, } \\
\text { oleoductos, atentados contra los } \\
\text { agentes de Colombia y violencia. } \\
1990 .\end{array}$ & $\begin{array}{l}\text { - Operación militar al } \\
\text { Palacio de Justicia. } \\
1985 . \\
\text { - Ley de indulto } 77 \text { de } \\
\text { 1989. Dejación de } \\
\text { armas en } 1990 \text { con el } \\
\text { M-19. } \\
\text { - Asamblea Nacional } \\
\text { Constituyente. 1991. } \\
\text { - Toma a casa verde, } \\
\text { operación ofensiva } \\
\text { militar contra el secre- } \\
\text { tariado de las FARC. } \\
\text { Conversaciones con } \\
\text { el EPL, Quintín Lame } \\
\text { y PRT. Partido Re- } \\
\text { volucionario de los } \\
\text { Trabajadores. } \\
\end{array}$ \\
\hline $\begin{array}{l}\text { Las guerrillas } \\
\text { al final del } \\
\text { siglo XX y } \\
\text { comienzos } \\
\text { del XXI }\end{array}$ & $\begin{array}{l}\text { - Se intensifica los ataques a las } \\
\text { bases militares (las Delicias....), } \\
70 \text { militares secuestrados. } \\
\text { - } \text { Los Paramilitares agrupados en las } \\
\text { autodefensas Unidas de Colombia, } \\
\text { AUC, aumentaron sus operaciones. } \\
\text { - Estos grupos al margen de la ley } \\
\text { causaron el desplazamiento ma- } \\
\text { sivo de millares de campesinos y } \\
\text { ejecutaron numerosas masacres. } \\
\text { - Las FARC cometen numerosos de- } \\
\text { litos que contribuyeron la ruptura } \\
\text { y radicalización del conflicto. } \\
\text { - Asesinato de la ex ministra Con- } \\
\text { suelo Araujo y secuestro del } \\
\text { senador Gechem Turbay. } \\
\text { - Acusaciones al Estado Colombiano } \\
\text { de violaciones de los Derechos } \\
\text { Humanos. } \\
\text { El narcotráfico y los grupos para- } \\
\text { militares han cometido delitos } \\
\text { atroces contra la sociedad colom- } \\
\text { biana. Estos delitos han desesta- } \\
\text { bilizado la economía y debilitado } \\
\text { las instituciones de la nación. }\end{array}$ & $\begin{array}{l}\text { - Celebración de acuer- } \\
\text { dos humanitarios } \\
\text { para la liberación } \\
\text { de secuestrados con } \\
\text { Ernesto Samper y } \\
\text { Pastrana Arango. } \\
\text { - Zona de despeje para } \\
\text { el inicio del fin del } \\
\text { conflicto con Pastrana } \\
\text { Arango. } \\
\text { - Plan Colombia 1999. } \\
\text { - Terminación de los } \\
\text { diálogos con la FARC. } \\
\text { - 2002-2006 Política de } \\
\text { seguridad democrá- } \\
\text { tica del presidente } \\
\text { Álvaro Uribe. } \\
\text { - Lucha contra el narco- } \\
\text { tráfico, paramilitares y } \\
\text { guerrilla y calificación } \\
\text { de narcoterroristas. } \\
\text { - Operaciones militares } \\
\text { contra las FARC. } \\
\text { Proceso de paz con } \\
\text { los paramilitares y su } \\
\text { desmovilización }\end{array}$ \\
\hline
\end{tabular}




\begin{tabular}{|c|c|c|}
\hline & & $\begin{array}{l}\text { y extradición de los } \\
\text { principales jefes de } \\
\text { estas organizaciones } \\
\text { criminales. } \\
\text { - Intensificación de } \\
\text { operaciones militares } \\
\text { contra la subversión. } \\
\end{array}$ \\
\hline $\begin{array}{l}\text { Estado co- } \\
\text { lombiano y } \\
\text { conflicto en } \\
\text { el siglo XXI }\end{array}$ & $\begin{array}{l}\text { - Amenaza terrorista alimentada por } \\
\text { - Sec narcotráfico. } \\
\text { - Surgimiento de bandas criminales } \\
\text { responsables de actos de des- } \\
\text { estabilización institucional en } \\
\text { importantes ciudades del país. } \\
\text { - Relación entre la clase política y } \\
\text { los paramilitares. } \\
\text { - Los denominados falsos positivos } \\
\text { han generado la investigación de } \\
\text { la Fiscalía General de la Nación } \\
\text { contra miembros del Ejercito Na- } \\
\text { cional. Considerados como viola- } \\
\text { ciones a los derechos humanos y } \\
\text { crímenes de lesa humanidad. } \\
\text { - Crisis humanitaria vivida por } \\
\text { Colombia debido al conflicto } \\
\text { armado. }\end{array}$ & $\begin{array}{l}\text { - Fortalecimiento de la } \\
\text { capacidad institu- } \\
\text { cional de las Fuerzas } \\
\text { Armadas del Estado } \\
\text { Colombiano. } \\
\text { - Negociaciones con las } \\
\text { AUC, Fuerzas Unidas } \\
\text { Colombianas y la } \\
\text { persecución a grupos } \\
\text { guerrilleros. } \\
\text { Proceso de paz con } \\
\text { las AUC, y la desmo- } \\
\text { vilización de } 18.000 \\
\text { combatientes. } \\
\text { - Operación Fénix } 2008 \\
\text { cayo el jefe guerri- } \\
\text { llero Raúl Reyes en } \\
\text { territorio ecuatoriano. } \\
\text { - Operación Jaque } 2008 \\
\text { de rescate a Ïngrid Be- } \\
\text { tancur y } 11 \text { militares, } \\
3 \text { asesores estadouni- } \\
\text { denses. } \\
\text { - Operación Camaleón } \\
\text { 2010, rescate de poli- } \\
\text { cías. } \\
\text { Utilización de bases } \\
\text { militares por parte de } \\
\text { los Estados Unidos. } \\
\text { gobiernol, en cabeza de } \\
\text { mos como la ONu. } \\
\text { La OEA, ha interve- } \\
\text { nido para facilitar la } \\
\text { negociación y la paz } \\
\text { del país }\end{array}$ \\
\hline
\end{tabular}


Se infiere de la Tabla 2, que la representación y la narrativa del conflicto social y político de Colombia en los libros de texto escolar contemporáneos de ciencias sociales de la educación básica secundaria y media colombiana, se puede comprender y explicar partir de lo que la literatura y los efectos políticos del Ilamado "conflicto" ha generado como "lugares comunes", que los libtos de texto escolar analizados, por lo demás, también reproducen o divulgan.

Al respecto, Jorge Giraldo Ramírez (2015), plantea una tipología de cuatro posiciones entre los autores de texto escolar, intelectuales, los políticos y las empresas ideológicas respecto a "la guerra que las guerrillas le declararon al Estado colombiano durante los años setenta, a su posterior escalada y a la emergencia de grupos paramilitares y narcotraficantes que hicieron más cruenta y compleja la contienda bélica..." (p. 173).

¿Cuáles son estas cuatro posiciones? (1) una de justificación explícita e implícita; (2) otra de inhibición; (3) una tercera de neutralización y (4) una cuarta de postura crítica. A continuación sintetizamos cada una de estas "posiciones" o "posturas" planteadas por Giraldo (2015: 173-176).

La posición justificadora. Reune los argumentos que pretenden convencernos de que los asuntos constitucionales y de justicia son razonables y en consecuencia las acciones congruentes con estas afirmaciones son correctas. Esto significa que las guerras civiles de corte reivindicativo nacionalista que pretenden crear nuevos Estados y las Ilamadas guerras revolucionarias que buscan el cambio de régimen gozan de permisividad y apoyo, hasta convertir el fenómeno bélico común.

La postura de inhición. Reúne a todos aquellos que no se pronunciaron sobre la guerra y permanecieron al margen de las discusiones que ella generó. La inhibición, según Giraldo, es muy explicable entre 1965 y 1980 cuando no había una amenaza guerrillera ni a la sociedad ni al Estado, y entre 1985 y 1993 cuando el país se vio en emergencia por cuenta del asedio brutal del narcotráfico, en especial del Ilamado cartel de Medellín. Pero no desde 1995, cuando la guerra insurgente alcanzó las mayores proporciones históricos y generó una enomre tragedia humanitaria. En momentos y ante crímenes de guerra sistemáticos, la inhibición puede tomar un viso de una justificación implícita. También esta postura puede ser explicable en tiempos de negociación: hay que evitar la crítica para no interferirla o destruirla.Esta posición refleja cierta perspectiva de simpatizantes de izquieda y defensores de derechos humanos que no desean ver ni criticar las violacienes fundamentales de los 
derechos humanos por parte de las guerrillas, por ejemplo: el reconocimiento de las victimas de sus secuestros.

La postura de neutralización. Identifica a quienes pretendieron ponerse por encima del Estado y de las guerrilas, como si fueran terceros o extranjeros que requirieran un aspecto de imparcialidad. Con mucha frecuencia, esta postura se expresó como una negociación de la legitimidad del Estado y la guerrilla, por igual.

La postura crítica. Es la de aquellos que no escondieron la cabeza, quienes se atrevieron a denunciar la ferocidad y los dolores de la guerra y cuestionaron las opiniones más aceptadas, sin rehuir sus responsabilidades morales ni ceder a las presiones de sus colectivos más cercanos. En esta postura, considera Giraldo, se apunta a decirles a los jefes de las guerrillas que la guerra que libran es ilegítima y que su efectos en materia de derechos humanos, terrorismo, corrupción- son de los más terribles.

\section{Conclusiones}

El contenido sobre el "conflicto" colombiano de los libros de texto escolar de ciencias sociales estudiados, se puede "tipologizar" siguiendo a James A. Robinson (2014: 28-30), quién elabora un marco de una interpretación más amplio de la economía política del país. Existen para James, por lo menos tres interpretaciones sobre la coexistencia de lo funcional y lo disfuncional del "conflicto" en Colombia: (a) La "lectura conservadora": "Colombia es básicamente un país exitoso en circunstancias difíciles y con mala suerte"; (b) La "lectura de la modernización radical/bloqueada": "Colombia no es un país exitoso debido a que su transición hacia una sociedad moderna se vio bloqueada por el yugo de los dos partidos políticos tradicionales y oligárquicos hasta 2012; (c) La "lectura de la sociedad dual" : "Colombia tiene una tradición de solidez democrática e institucional paralela a la guerra civil y al negocio de la droga debido a la manera particular como el Estado colombiano se formó históricamente y se relacionó con su territorio y sus ciudadanos (..).

Los libros de texto reflejan que los conflictos sociales y políticos no sólo tienen causas estructurales, sino que también son el resultado de las percepciones sociales. En este marco, se considera que mientras las representaciones en los libros de texto pueden reflejar diversas situaciones 
conflictivas en la sociedad, ellos en sí mismos, no necesariamente tienen una influencia directa en los conflictos.

La noción de "conflicto" se abre paso en los debates didácticos y en el contenido de los libros de texto escolar. No obstante, un enfoque centrado en el conflicto no siempre es considerado como una necesidad porque, por ejemplo, se asume que otras consideraciones pedagógicas son prioritarios. Las nociones de conflicto, que son parte de una sociedad y de la imagen de ella en sí misma, puede encontrar su espacio de tratamiento y presencia en los libros de texto sobre la base de ideas pedagógicas y didácticas.

El análisis del contenido de los libros de texto escolar colombianos de ciencias sociales, no pretende tanto ofrecer un concepto alternativo, sino contribuir a revisar estereotipos, maneras de plantear el "conflicto", omisiones históricas, énfasis, imagenes, su evolución y giros en su narrativa histórica, etc. Todo esto, con el fin de tener una mayor claridad claridad sobre la naturaleza del conflicto en Colombia.

\section{Referencias bibliográficas}

CEPEDA, F. (2001). Haciendo paz. Reflexiones y perspectivas del proceso de paz en Colombia. Bogotá: Fundación ideas para la paz.

DUNCAN, D. (2017). Memoria, ciencia y política. Diario El País. Marzo 10 de 2017. En: http://www.elpais.com.co/opinion/columnistas/gustavo-duncan/memoria-ciencia-ypolitica.html Consulta 29-03-2017.

ENTELMAN, R. (2002). Teoría de conflictos. Barcelona: Editorial Gedisa.

GIRALDO, J. (2015). Las ideas en la guerra. Justificación y crítica en la Colombia contemporánea. Bogotá: Debate. Prólogo de Daniel Pécaut.

GUERRA, M \& PLATA, J. (2005). Estado de la investigación sobre el conflicto, postconflicto, reconciliación y papel de la sociedad civil en Colombia. (2005). Revista de Estudios sociales. No. 21. Pp. 81-92.

LEWIN, J.E. (2015). Coincidencias y divergencias de los 14 relatos sobre la guerra. En: http://lasillavacia.com/print/49558\# Consulta realizada el 28-09-2015

KORINMAN, M. (2005). Enseigner la nation. Géopolitique des manuels. Ramoinville Saint-agne: Éditions éres.

MONCAYO, V.M. \& PIZARRO, E. (2015). Contribución al entendimiento del conflicto armado en Colombia. Comisión Histórica del Conflicto y sus Victimas. (CHCV). En: http://www.coljuristas.org/documentos/adicionales/version_final_informes_CHCV. pdf consulta 29-03-2017

MEDINA, M. (2003). Tiempos de paz. Acuerdos en Colombia, 1902-1994. En: Colombia 2003. Bogotá: Editorial del Instituto Distrital de Cultura y Turismo. Pp. 15-32. 
El conflicto social y político colombiano en los libros de texto escolar de ciencias sociales: representación, diversidad y narrativa

Miguel Ángel Gómez Mendoza y María Victoria Alzate Piedrahita

OTTO, M. \& STÖBER, G. (2012). Georg. Schulbuch und Konflikt. En: Edumerenes.net. http://www.edumeres.net/informationen/glossar/schulbuch-und-konflikt.html Consulta realizada el 18 de mayo de 2016.

PALACIOS, M. (2001). De populistas, mandarines y violencias. Luchas por el poder. Bogotá: Editorial Norma.

PÉCAUT, D. (2001). Guerra contra la sociedad. Bogotá: Editorial Norma.

PIZARRO, E. (2000). ¿Representación ficticia? En: El Espectador, agosto 26, 2000.

POSADA, E. (2003). 'llegitimidad' del estado en Colombia. Sobre los abusos de un concepto. Bogotá: Libros de Cambio.

POSADA, E. (2003a). El desafío de las ideas. Ensayos de historia intelectual y política de Colombia. Medellín: Fondo Editorial Universidad Eafit.

RAMÍREZ, W. (2000). Violencia, guerra civil, contrato social. En: Colombia medio siglo. Balances y perspectivas. Bogotá: Instituto de Estudios Políticos y Relaciones Internacionales de la Universidad Nacional de Colombia.

ROBINSON, J.A. (2014). La historia "definitiva" del paramilitarismo. En: El Tiempo. Sábado 11 de octubre de 2014.

TAWIL, S. \& HARLEY, A. (2004). Education, Conflict and Social Cohesion. Geneva: UNESCO International Bureau of Education.

URICOCHEA, F. (2000). Cuál guerra civil!. En: El Tiempo. 22 de octubre de 2002. http:// www.eltiempo.com/archivo/documento/MAM-1281087

VV.AA. Contribución al entendimiento del conflicto armado en Colombia. Comisión Histórica del Conflicto y sus Víctimas Contribución al entendimiento del conflicto armado en Colombia. Febrero de 2015. https://www.mesadeconversaciones.com. co/sites/default/files/Informe\%20Comisi_n\%20Hist_rica\%20del\%20Conflicto\%20 y\%20sus\%20V_ctimas.\%20La\%20Habana\%2C\%20Febrero\%20de\%202015.pdf Consulta 28 de septiembre de 2015.

\section{Nota:}

Artículo elaborado en el marco de la ejecución del proyecto: "El conflicto social y político colombiano en los libros de texto escolar de ciencias sociales: perspectiva histórica e internacional" Código Vicerrectoría de Investigaciones, Extensión e Innovación -Universidad Tecnológica de Pereira-Colombia: 4-15-9. Proyecto sin financiación. Grupo de Investigaciones Pedagógicas y Educativas GIPE (Categoría A ColcienciasCOL0012749) Investigador principal: Miguel Ángel Gómez Mendoza. Coinvestigadora: María Victoria Alzate Piedrahita . 